\title{
FOREIGN TRADE AND PRODUCTION IN 2015: CHANGE OF GEOGRAFY
}

\author{
A.Knobel
}

On the basis of the results of the first eight months of 2015, it can be concluded that industries where growth in domestic output is observed simultaneously with a drop in competitive import are the agriculture and the food industry. At the same time, substitution of consumption of investment goods - from foreign ones to domestic ones - does not take place: a decline in economic activities is accompanied by a drop both in domestic production and import.

Volatility of the national currency (some appreciation of the national currency in April-May followed by depreciation to the level of February-March in July-August) did not have a significant effect either on the dynamics of export or that of import: participants in foreign economic activities did not start to change their business decisions in response to short-term appreciation or weakening of the exchange rate of the national currency.

It is to be noted that growth in the export of the non-primary sector either in monetary or physical terms did not take place, either. An insignificant increase in physical volumes of the export was observed only in groups of commodities with a low- and mid-level of processing (non-diversified ones).

\section{The Dynamics of Export and Import}

From the beginning of 2015, the dynamics of foreign trade of Russia was determined primarily by depreciation of the ruble, general decline of economic activities and the Russian food embargo. In addition to the above, a drop in prices on energy commodities, sanctions and politically motivated reduction of the extent of trade with Ukraine affected the export.

\section{The Aggregate Export and Import}

In the first eight months of 2015, changes in export and import took place simultaneously (Fig. 1) which situation points to quite a stable correlation of export and import in the pattern of trade. The foreign trade balance remained a positive one during the current year. Despite substantial changes in prices on energy commodities, a decrease in export was somewhat lower (except for August) than that in import which was affected primarily by a drop in the purchasing power of the ruble. In February 2015, the export's highest index of $81.6 \%$ as compared to the respective index of 2014 was registered; after that the export started to fall and in August amounted to $61.1 \%$ year on year. The import fluctuated in the range of $57.7-65.9 \%$ of the volumes of the respective periods of 2014.

Export and Import of Agricultural Products and Food Industry Products ${ }^{1}$

In the first eight months of 2015, trade in agricultural and food industry products was more volatile (as percentage of the respective indices of the previous year) (Fig. 2). In January 2015, the volume of export exceeded by $15.7 \%$ the respective index of the previ-

1 Groups of Harmonized System Codes of Foreign Economic Activities 01-24.

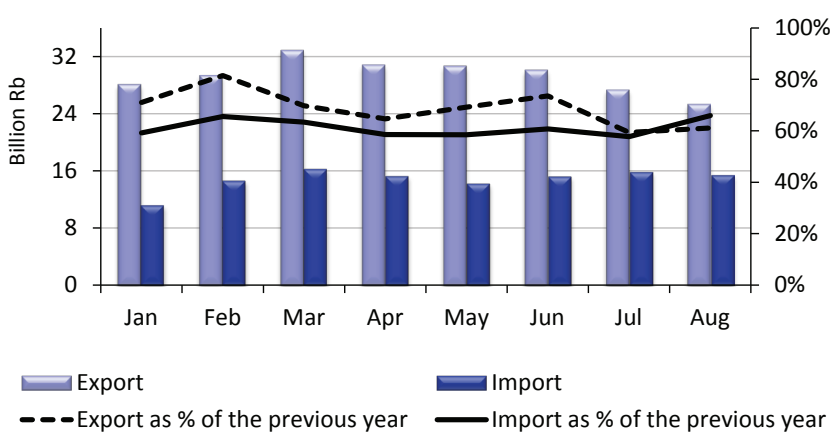

Fig. 1. Dynamics of Russian foreign trade in 2015

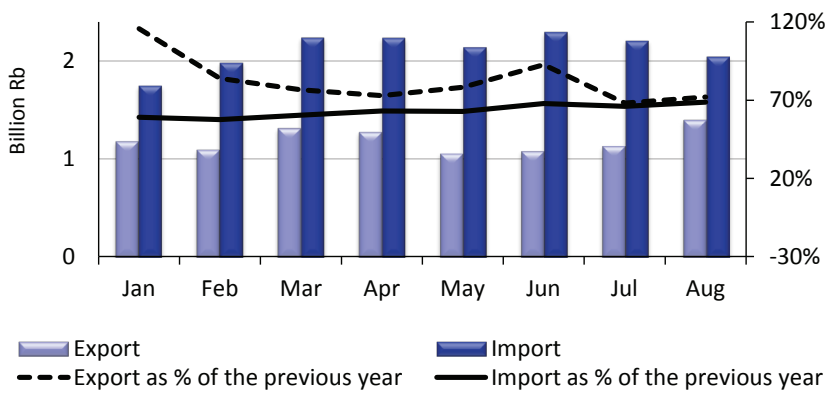

Fig. 2. Dynamics of Russia's trade in agricultural and food industry products in 2015

ous year, while that of import was $41.2 \%$ lower, however, the foreign trade balance remained a negative one. It is to be noted in particular that in February the export fell to $83.8 \%$ of the index of the previous year, while further dynamics of trade in that group of commodities was close to the dynamics of the aggregate trade. 


\section{Export and Import of Chemical Industry Products ${ }^{1}$}

In January-July 2015, a drop in chemical industry products was lower than that in import, however, in August the indices of import and export (as \% of the same period of 2014) were almost similar: $71.3 \%$ and $74.4 \%$, respectively.

Export and Import of Primary Metals and Fabricated Metal Products ${ }^{2}$

In January-August 2015, the volume of export of primary metals and fabricated metal products exceeded the index of the previous year only in February $(+3.7 \%)$, but as early as August a drop was registered $(-33.5 \%)$. The import was more stable - it fluctuated in the range of $54.5-70.0 \%$ of the volumes of the same period of the previous year (Fig. 4).

Export and Import of Machines and Equipment and Other Industrial Goods ${ }^{3}$

The only large group of commodities where growth in export is observed as compared to 2014 for more than a month (February and March) is "machines and equipment". It is to be noted that in April-July the export was steadily falling (\% as compared to the same period of 2014). The import of that group of commodities showed the most dramatic decrease which situation points to a more dramatic drop in demand on durable goods (Fig. 5).

Random Comparison of Changes in Average Prices and Volumes of Export

In random comparison of changes in the ruble prices of the export and monetary volumes of the export in January-August 2015 (Fig. 6), it can be noted that as regards goods on which ruble prices grew at a higher rate a smaller drop in monetary volumes of the export was registered. Growth in the volumes of export was observed only as regards paper pulp and fertilizers ${ }^{4}$.

Comparison of the Dynamics of Trade and Production of Some Goods

\section{The Agriculture and the Food Industry}

A random comparison of a number of positions of the agriculture and the food industry points to the fact that changes in the trade balance in physical terms are largely compensated by changes in production. It is to be noted that consumption (measured as changes in production less the net export) by key positions of agricultural and ready-made food products was chang-

1 Groups of Harmonized System Codes of Foreign Economic Activities 28-40.

2 Groups of Harmonized System Codes of Foreign Economic Activities 71-83.

3 Groups of Harmonized System Codes of Foreign Economic Activities 84-97.

4 It is to be noted that growth in export of electric power is related to a great extent to power supplies to the north of Ukraine in exchange for Ukrainian power supplies to Crimea.

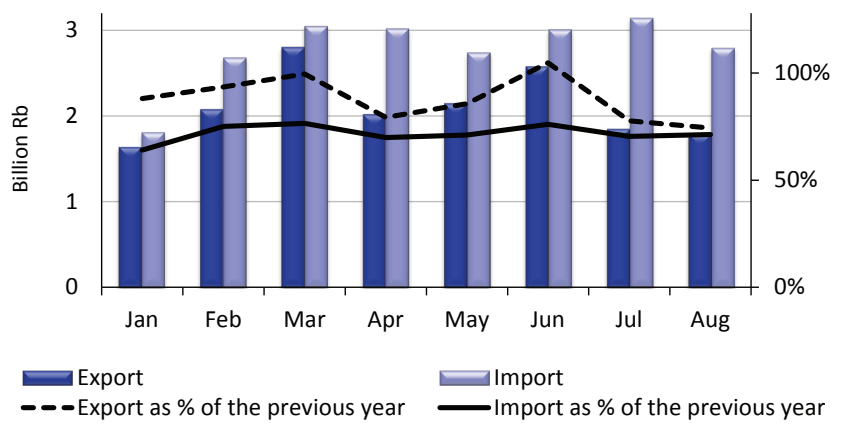

Fig. 3. Dynamics of Russia's trade in chemical products in 2015

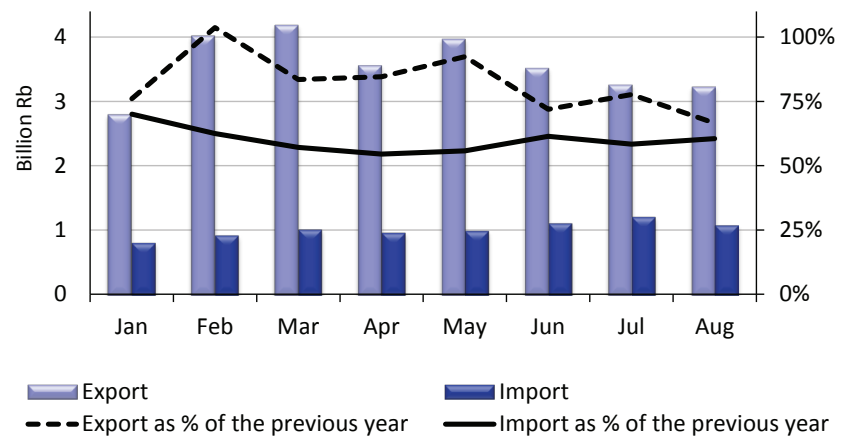

Fig. 4. Dynamics of Russia's trade in primary metals and fabricated metal products in 2015

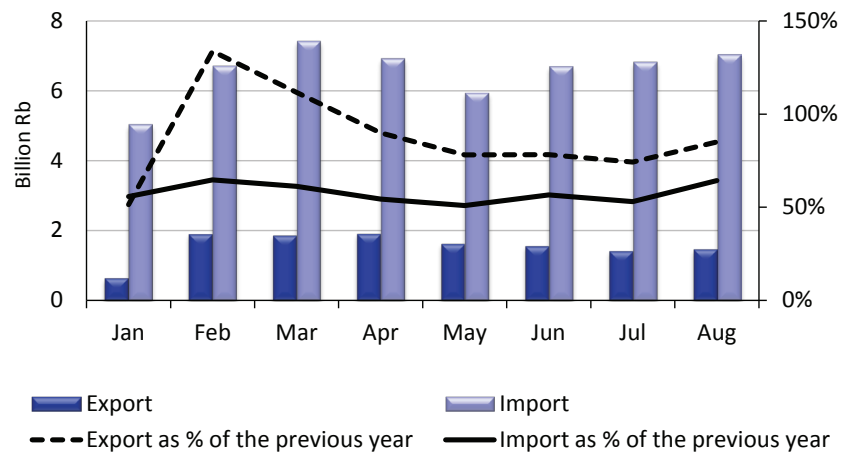

Fig. 5. Dynamics of Russia's trade in machines and equipment in 2015

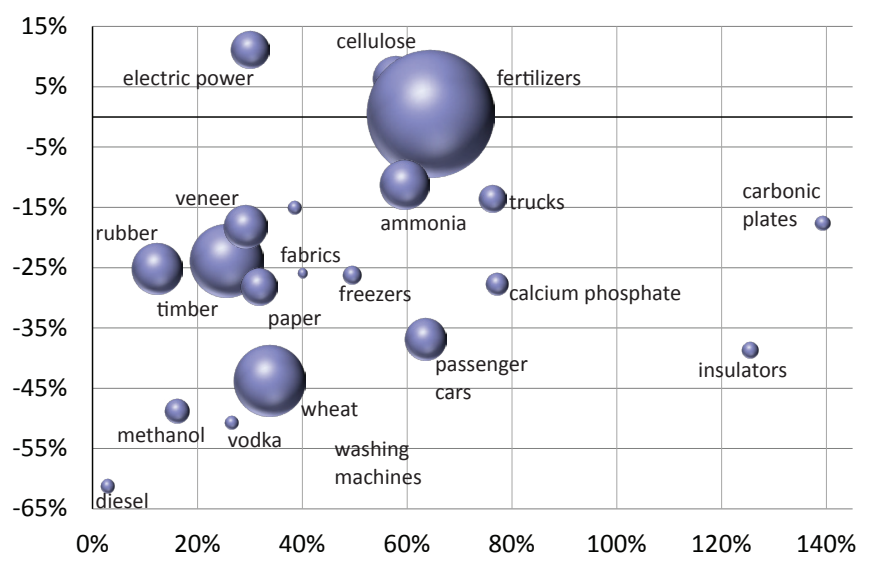

Fig. 6. The diagram of dispersion of changes in monetary volumes of the Russian export in January-August 2015 depending on changes in the average prices (in rubles) 
ing smoothly. However, there was a decrease in general consumption by all the positions under review, except for poultry meat.

It can be concluded that changes in production compensate changes in trade, but by all the positions, except for poultry meat and flour, an increase in the volumes of production turned out to be lower than a change in the trade balance. Also, it is to be noted that the import decreased considerably (manifold) by all the commodity positions, while the export of flour and meat increased; it is noteworthy that only growth in the export of flour was considerable (110\%).

\section{Industrial Goods with a Low Level of Processing}

Export, production and consumption of goods with a low level of processing do not show common trends. Manufacturing of plastic materials in original forms showed substantial growth which happened to be lower than an increase in the trade balance. On the contrary, growth in production of cast iron exceeded by $200 \%$ its export. The data of the Rosstat on changes in production of nonferrous metals is available only as a percentage of the previous year, but not in physical volumes.

\section{Vehicles, Household Appliances and Footwear}

Manufacturing of vehicles decreased dramatically by all the positions. It is to be noted that the trade balance (in units) as regards vehicles increased against a dramatic decrease (often manifold) in import. Reduction of the export of busses, trucks and cars was manifold less substantial than that of import and output. Substantial growth in export by such commodity positions as "tractors" and "carriages" was observed in a situation of a dramatic decrease in output by those commodity positions. Such an effect can be explained both by a time lag between output and export of finished products and a dramatic drop in domestic demand.

The output of household appliances (washing machines, refrigerators, freezers and receiving TV equipment) showed a substantial decrease (by tens of percent) as compared to the index of the previous year. It is to be noted that the trade balance increased by those commodity positions due to reduction of the import by tens of percent; reduction of the export was substantial, too, but lower in absolute terms.

The output of footwear fell by $18 \%$ to $58.6 \mathrm{~m}$ pairs, while the consumption, by a quarter.

Despite growth in the trade balance of all the commodity positions under review, there was a substantial decrease of tens of percent in output and consumption of those goods. The import fell by all the commodity positions, while the export showed a differently directed movement.

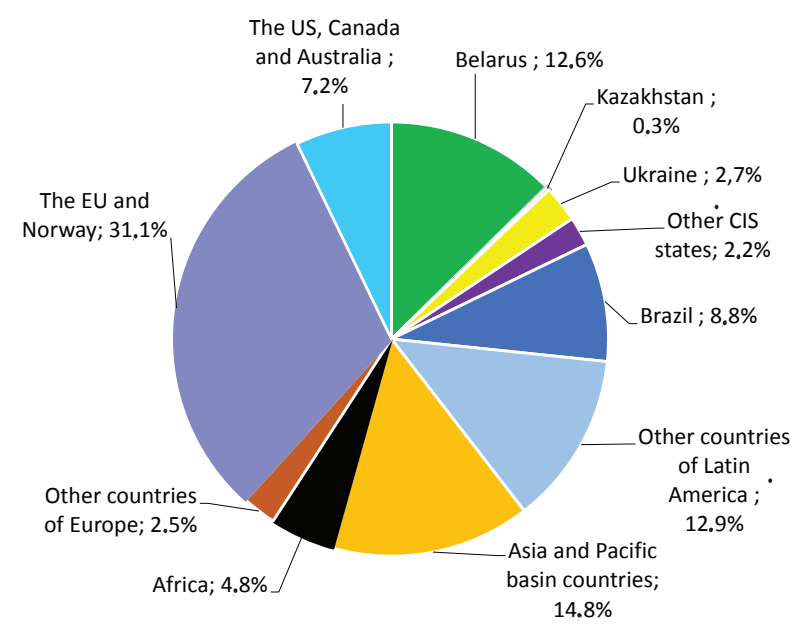

Note: preservation of insignificant import from the EU, Norway, the US, Canada and Australia can be explained by some exceptions made from the embargo, for example, for delactosed dairy products.

Fig. 7. Geographic distribution of the import of that commodity group in August 2013 - July 2014

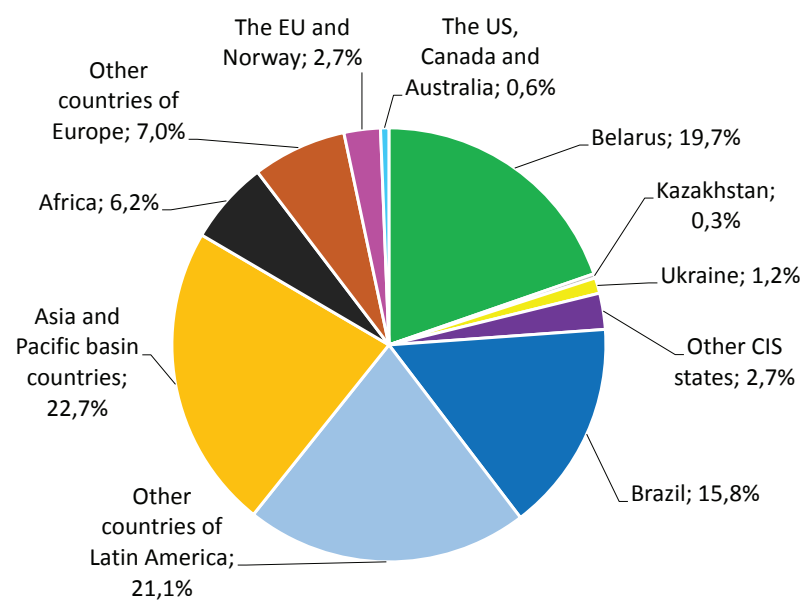

Note: preservation of insignificant import from the EU, Norway, the US, Canada and Australia can be explained by some exceptions made from the embargo, for example, for delactosed dairy products.

Fig. 8. Geographic distribution of the import of that commodity group in September 2014 - August 2015

\section{Food Products Subjected to the Embargo}

Geographic distribution of the import of goods on which the ban is imposed

Changes in the geographic distribution of the import of commodity groups subjected to the Russian embargo a year before and after introduction of the countersanctions are shown in Fig. 7 and Fig. 8, respectively.

As seen from Table 1, a drop of $39.5 \%$ in the trade during the year following the introduction of the embargo (as compared to the year before introduction of the embargo) exceeds insignificantly the volumes of import from the countries -- in respect of which sanctions were introduced -- which accounted for $38.3 \%$ of the import a year before the sanctions were imposed. 
SHARES AND VOLUMES OF THE IMPORT OF COMMODITY POSITIONS SUBJECTED TO SANCTIONS

\begin{tabular}{|c|c|c|c|c|c|}
\hline \multirow{2}{*}{ Country/ Region } & \multicolumn{2}{|c|}{ The share in the import (\%) } & \multicolumn{2}{|c|}{$\begin{array}{l}\text { The volume of the } \\
\text { import (billion USD) }\end{array}$} & \multirow{2}{*}{$\begin{array}{c}\text { Change in the volume } \\
\text { of import (\%) } 9.2014- \\
8.2015 \text { against } \\
8.2013-7.2014\end{array}$} \\
\hline & $8.2013-7.2014$ & $9.2014-8.2015$ & $8.2013-7.2014$ & $9.2014-8.2015$ & \\
\hline Belarus & 12.6 & 19.7 & 2.77 & 2.61 & -5.8 \\
\hline Kazakhstan & 0.3 & 0.3 & 0.06 & 0.04 & -31.2 \\
\hline Ukraine & 2.7 & 1.2 & 0.60 & 0.15 & -74.4 \\
\hline Other CIS states & 2.2 & 2.7 & 0.48 & 0.36 & -25.2 \\
\hline Brazil & 8.8 & 15.8 & 1.94 & 2.09 & 8.1 \\
\hline Other countries of Latin America & 12.9 & 21.1 & 2.82 & 2.80 & -0.8 \\
\hline Asia and Pacific basin countries & 14.8 & 22.7 & 3.25 & 3.01 & -7.3 \\
\hline Africa & 4.8 & 6.2 & 1.06 & 0.82 & -22.4 \\
\hline The US, Canada and Australia & 7.2 & 0.6 & 1.57 & 0.08 & -94.8 \\
\hline The EU and Norway & 31.1 & 2.7 & 6.83 & 0.36 & -94.7 \\
\hline Other countries of Europe & 2.5 & 7.0 & 0.56 & 0.93 & 67.5 \\
\hline Total & & & 21.95 & 13.27 & -39.5 \\
\hline
\end{tabular}

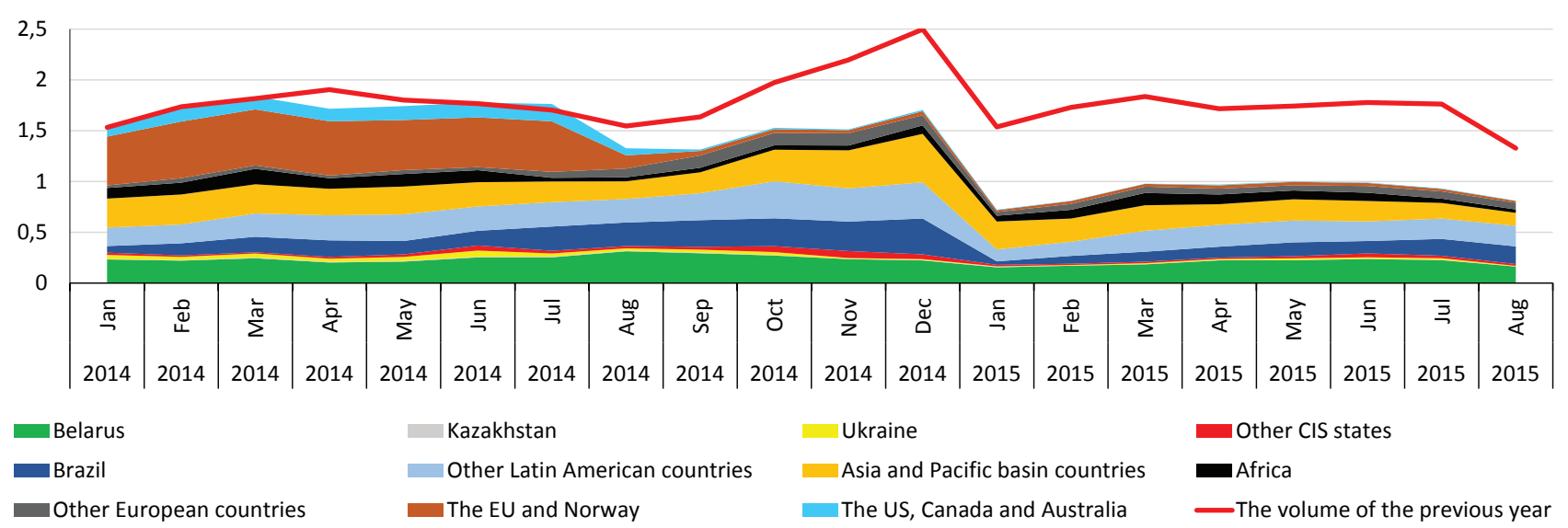

Fig. 9. Geographic distribution of the import of the group of commodities subjected to the embargo in the 2014-2015 period, in billion USD

It can be concluded that the flow of goods of that category from third countries did not virtually change, however, it is to be taken into account that the import of other agricultural and food products fell by $27.5 \%$. It can be stated that an additional decrease in the import of goods subjected to the embargo (as compared to the level which is typical of other agricultural and food products) amounted only to $14.9 \%$. It is to be noted that the import from European countries in respect of which sanctions were not introduced and which countries are not member-states of the CIS showed growth of $67.5 \%$. Also, the import from Brazil grew by $8.1 \%$, while that from other Latin American countries and Belarus changed insignificantly: $+0.8 \%$ and $-5.8 \%$, respectively.

\section{Dynamics of Prices on Some Types of Products}

In Fig. 10, dynamics of prices on some types of products subjected to sanctions (as \% of the price in the same period of 2013) is shown. As seen from the diagram, in August-September 2014 prices on meat and fish rose dramatically, while the reaction of prices on vegetables and fruits to the embargo was weaker. Late in 2014 and early in 2015, prices were falling dramatically which situation can be explained by a switchover of consumers to less expensive goods due to depreciation of the ruble (a similar effect was observed in other commodity groups, too) and exhaustion of the price surge which took place due to a dramatic dropout of a large share of goods supplied from countries in respect of which sanctions were introduced.

In the first eight months of 2015, the dynamics of Russia's foreign trade was primarily determined by depreciation of the ruble, general decline in economic activities and imposition by Russia of the food embargo.

Dynamics of changes in the import had common behavior which was typical of all the large commodity groups which situation points to similarity of factors which were behind the decrease. The highest relative 


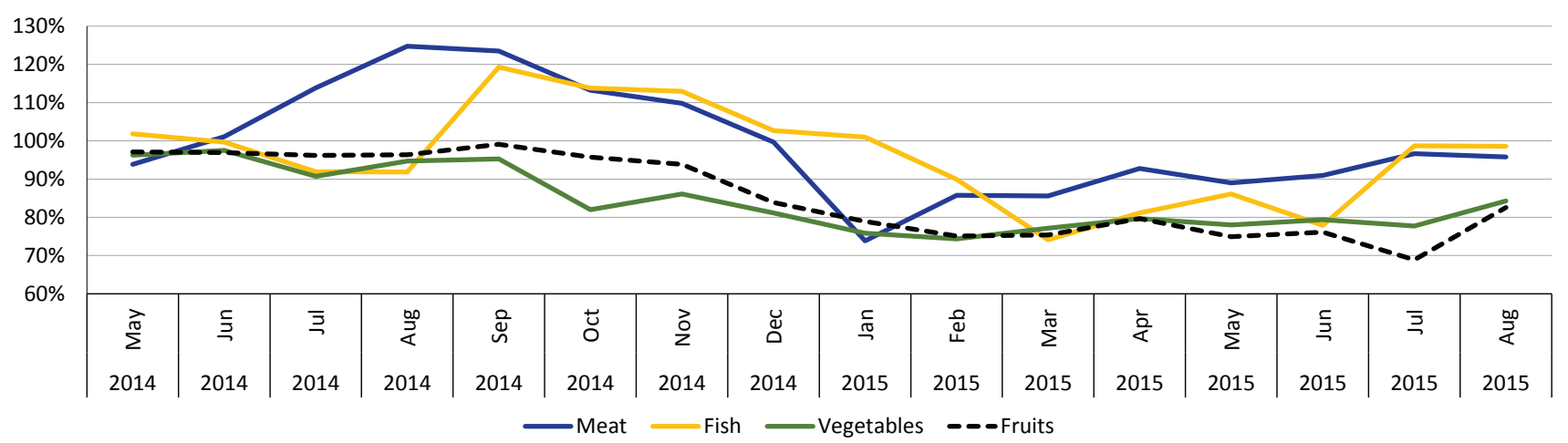

Fig. 10. Dynamics of prices on some types of products subjected to sanctions (as \% of the price in the same period of 2013)

drop in the import was observed in the "machines and equipment" commodity group which factor points to shrinkage of demand on investment and durable goods. Simultaneously, a drop in the output of respective domestic products is observed. So, substitution of consumption of investment goods - from import ones to domestic ones - does not take place: a decline of economic activities is accompanied by a drop both in domestic output and import.

Sectors where growth in domestic output is observed simultaneously with a drop in competitive import are the agriculture and the food industry.

The export is affected among other things by falling prices on energy commodities, sanctions and a politically motivated reduction of trade volumes with Ukraine.

Fluctuations of the exchange rate of the national currency (some appreciation in April-May followed by depreciation to the level of February-March in JulyAugust) did not have a considerable effect either on the dynamics of the export or that of the import: participants in foreign economic activities did not start to change their business decisions in response to the short-term appreciation or weakening of the exchange rate of the national currency.

Depreciation of the ruble did not result in the expected growth in the export of the non-primary sector either in monetary or physical terms. An insignificant increase in physical volumes of the export was observed only in groups of commodities with a lowand mid-level of processing (non-diversified ones). The highest relative indices of the export (the lowest drop in the export) are observed in the outputs of the chemical industry and equipment: $88.1 \%$ and $87.4 \%$, respectively, against the volumes of the previous year.
A lack of growth in export revenues with explicit growth in competitive advantages of final products of the non-primary sector is related to the fact that Russian exporters are integrated to a greater extent than, for example, in 1998 in global chains of added value and use actively imported component parts in their costs. It is particularly evident in manufacturing and export of cars: despite growth of $60-70 \%$ in export ruble prices, a drop in the volumes of export supplies amounts to $20-30 \%$.

As regards goods subjected to the food embargo, during the year within which countersanctions were imposed the import of relevant goods fell approximately by the value of the import of food from countries in respect of which the embargo was introduced. It means that the flow of that category of goods from third countries did not virtually change; it is to be noted that the import from European countries in respect of which sanctions were not introduced and which countries are not CIS member-states showed growth of $67.5 \%$.

Generally, the drop-out import of food from the EU, the US, Canada, Australia and Norway was replaced by the relevant import from other countries (with adjustment to the general decrease due to depreciation). It is to be noted that in late 2014 early in 2015 prices on imported food were falling dramatically which situation can be explained both by a switchover of consumers to less expensive (in USD) goods due to depreciation of the ruble (a similar effect was observed in other groups of commodities, as well) and completion of a price surge which took place due to a dramatic drop-out of a large share of goods supplied from the countries in respect of which sanctions were imposed. 